\title{
PENGARUH RISIKO PEMBIAYAAN DAN PROPORSI PEMBIAYAAN NON INVESTASI TERHADAP PROFIT DISTRIBUTION MANAGEMENT PERBANKAN SYARIAH
}

\author{
Lia Dwi Martika \\ lia_dwimartika@yahoo.com
}

\begin{abstract}
Islamic banks should be able to maintain the confidence of depositors to keep their funds in Islamic banks. One effort to do that is through the profit distribution management as well as possible so that depositors in Islamic banks keep their money in the bank. Profit Distribution Management (PDM) is an activity performed managers to manage the distribution of profits to fulfill responsibility of profit sharing Islamic banks to their depositors. The purpose of this research to analyze the influence of Risk Financing and Non Investment Financing Proportion toward Profit Distribution Management. This research was conducted in Islamic banks exist in Indonesia, Malaysia and the countries which are Gulf Cooperation Council (GCC). The sampling technique used was purposive sampling. Analysis of the data used is descriptive quantitative method and statistical analysis used panel data multiple regression with Eviews program. The test results showed risk financing significantly positive influence the profit distribution management. The results of hypothesis testing also found that the proportion of non-investment financing no significant effect on the profit distribution management in Islamic banks in Indonesia, Malaysia and the countries which are Gulf Cooperation Council (GCC).

Keywords : Risk Financing, Non Investment Financing Proportion, Profit Distribution Management, Islamic banks in Indonesia, Malaysia and GCC.
\end{abstract}

\section{PENDAHULUAN}

Konsep bagi hasil bisa berjalan jika dana deposan di bank syariah diinvestasikan terlebih dahulu ke dalam usaha, sehingga dari keuntungan usaha tersebut kemudian dibagikan kepada deposan. Besarnya penentuan porsi bagi hasil antara pemilik dana (shahibul maal) dan pengelola dana (mudharib) ditentukan sesuai kesepakatan bersama dan harus terjadi dengan adanya kerelaan (An-Tarodhin) antara masing-masing pihak tanpa adanya unsur paksaan. Sehingga terlihat jelas bahwa konsep bagi hasil ini menjadi pembeda antara bank syariah dan bank konvensional.
Salah satu stakeholders yang menjadi penentu keberlangsungan bank syariah yaitu deposan (shahibul maal). Oleh karena itu, bank syariah harus mampu menjaga kepercayaan deposan untuk tetap menyimpan dananya di bank syariah. Salah satu upaya yang dapat dilakukan yaitu melalui pengelolaan penditribusian keuntungan dengan sebaik mungkin agar deposan di bank syariah tetap menyimpan dananya di bank tersebut. Penelitian Mangkuto (2004) juga menegaskan bahwa faktor yang menjadi pertimbangan masyarakat menginvestasikan dananya di bank syariah adalah faktor return bagi hasil. Selain itu, Muhlis (2011) dalam disertasinya memiliki 
kesimpulan utama bahwa perilaku menabung di bank syariah paling dipengaruhi oleh tingkat bagi hasil (profit distribution). Dari hasil penelitian tersebut dapat diimplikasikan bahwa sangatlah penting bagi bank syariah untuk menjaga kualitas distribusi keuntungan (profit distribution). Menurut laporan Ernst \& Young World Islamic Banking Competitiveness Report 2014-2015, aset perbankan syariah internasional telah melampaui USD 778 miliar pada tahun 2014 dan Laju Pertumbuhan Majemuk Tahunan (Compound Annual Growth Rate) sebesar 17\% antara tahun 2009 dan 2013. Pada enam pasar syariah utama (Uni Emirat Arab, Qatar, Arab Saudi, Indonesia, Malaysia dan Turki), aset perbankan syariah diperkirakan mencapai US\$ 1,8 triliun pada tahun 2019. Gairah pasar syariah di wilayah Teluk memberikan gambaran yang kuat untuk masa depan keuangan Islam. Ini artinya bank syariah di negaranegara tersebut harus menjaga eksistensi yang sudah terbangun, salah satunya dengan menjaga kepercayaan deposan terhadap bank syariah.

Hal tersebut yang melatarbelakangi keinganan penulis untuk melakukan penelitian lebih lanjut tentang risiko pembiayaan dan proporsi pembiayaan non investasi yang mempengaruhi Profit Distribution Management pada bank syariah di negara Indonesia, Malaysia dan negara yang tergabung dalam Dewan Kerjasama Negara Arab di Teluk (Gulf Cooperation Council (GCC).

\section{KERANGKA TEORITIS DAN HIPOTESIS}

\section{Shariah Enterprise Theory}

Shariah Enterprise Theory

(SET) merupakan enterprise theory yang telah diinternalisasi dengan nilai-nilai Islam guna menghasilkan teori yang transendental dan lebih humanis. Enterprise theory, menurut Triyuwono (2003), mampu mewadahi kemajemukan masyarakat (stakeholders), hal yang tidak mampu dilakukan oleh proprietary theory dan entity theory. Hal ini karena konsep enterprise theory menunjukkan bahwa kekuasaan ekonomi tidak lagi berada di satu tangan (shareholders), melainkan berada pada banyak tangan, yaitu stakeholders (Triyuwono, 2003). Oleh karena itu, enterprise theory ini lebih tepat untuk suatu sistem ekonomi yang mendasarkan diri pada nilai-nilai syariah. Shariah enterprise theory dapat dikatakan merupakan suatu social integration yang berawal dari adanya kepentingan emansipatoris untuk membebaskan knowledge yang selalu terperangkap dalam dunia materiil menjadi suatu knowledge yang juga mempertimbangkan aspek non materiil.

\section{Teori Stakeholder}

Perusahaan merupakan suatu entitas yang tidak hanya beroperasi untuk kepentingannya sendiri, melainkan harus memberikan manfaat bagi stakeholder. Stakeholder merupakan individu, sekelompok manusia, komunitas atau masyarakat baik secara keseluruhan maupun secara parsial yang memiliki hubungan serta kepentingan terhadap perusahaan. Stakeholder mampu untuk mengendalikan atau memiliki 
kemampuan untuk mempengaruhi pemakaian sumber-sumber ekonomi yang digunakan oleh perusahaan. Oleh karena itu, perusahaan akan bereaksi dengan cara-cara yang memuaskan keinginan stakeholder saat stakeholder mengendalikan sumber ekonomi yang penting bagi perusahaan (Anis dalam Tamba, 2011). Menurut Gray, Kouhy dan Adam (1994) dalam Chariri dan Ghozali (2007) mengatakan bahwa kelangsungan hidup perusahaan tergantung pada dukungan stakeholder dan dukungan tersebut harus dicari sehingga aktivitas perusahaan adalah untuk mencari dukungan tersebut.

\section{Pengaruh Risiko Pembiayaan (RP) terhadap Profit Distribution Management (PDM)}

Risiko pembiayaan (RP)

digunakan untuk mengukur tingkat permasalahan pembiayaan yang dihadapi oleh bank syariah. RP dapat diukur dengan Non Performing Financing (NPF). NPF merupakan rasio untuk mengukur kemampuan bank dalam menjaga risiko kegagalan pengembalian kredit oleh debitur. Semakin baik kualitas pembiayaan yang disalurkan bank, makin kecil tingkat NPF. Semakin tinggi rasio NPF, menunjukkan kualitas pembiayaan bank syariah semakin buruk. Karena rasio ini menunjukkan besaran tingkat kegagalan yang ditimbulkan oleh bank. Apabila bank memiliki tingkat resiko pembiayaan (NPF) yang tinggi, hal tersebut mengindikasikan bahwa kemampuan bank dalam menghasilkan pendapatan akan menurun, dan bagi hasil yang akan diberikan kepada nasabah akan kecil.
H1 : Risiko
pembiayaan berpengaruh positif

terhadap profit distribution management.

\section{Pengaruh Proporsi Pembiayaan Non Investasi (PPNI) terhadap Profit Distribution Management (PDM)}

Proporsi Pembiayaan Non Investasi (PPNI) bank syariah mengacu pada pembiayaan dengan tingkat tetap (sisi piutang). Pembiayaan Non Investasi pada bank syariah dilakukan dengan akad Murabahah, Salam, Istishna' dan Ijarah. Pembiayaan jenis ini menggunakan tingkat harga dan keuntungan yang disepakati di awal kontrak. Selama kontrak ini berjalan dan pembayaran diangsur, waktu semakin berjalan. Saat berjalannya waktu, terdapat kemungkinan terjadi perubahan tingkat suku bunga, sehingga bank syariah berhadapan dengan fund gap antara asset returns yang sudah ditetapkan di awal kontrak dengan dana deposan yang digunakan untuk proses pembiayaan non investasi tersebut.

Oleh karena itu besarnya PPNI ini akan menentukan tingkat dimana bank syariah melakukan PDM untuk return mismatch dalam keadaan pasar dimana terdapat perubahan suku bunga (Farook dkk., 2009). Oleh karena itu, semakin tinggi tingkat rasio, dimana angka proporsi pembiayaan non investasi semakin tinggi, sehingga semakin tinggi tingkat PDM.

H2 : Proporsi pembiayaan non investasi berpengaruh positif terhadap profit distribution management.

Pengaruh Risiko Pembiayaan (RP) dan Proporsi Pembiayaan Non Investasi (PPNI) terhadap Profit Distribution Management (PDM) 


\begin{abstract}
Hasil penelitian Nasrah Mawardi (2005) menunjukkan bahwa NPF pengaruh yang negatif terhadap return bagi hasil. Sehingga apabila RP semakin besar, maka bagi hasil semakin rendah. Bila dikaitkan dengan teori stakeholder, maka bank syariah akan menaikan tingkat PDM yang mengacu pada suku bunga untuk mengelola deposannya. Sehingga tingkat PDM akan bertambah dikarenakan tingkat pofit distribution yang diperoleh deposan sudah rendah. Begitu pula dengan besarnya PPNI akan menentukan tingkat dimana bank syariah melakukan PDM. Semakin tinggi tingkat rasio PPNI, sehingga semakin tinggi tingkat PDM.
\end{abstract}

H3 : Risiko pembiayaan dan Proporsi pembiayaan non investasi secara simultan berpengaruh positif terhadap profit distribution management.

\section{METODOLOGI}

Penelitian ini menggunakan metode penelitian deskriptif dengan pendekatan kuantitatif. Populasi dalam penelitian ini adalah bank syariah yang terdapat di Indonesia, Malaysia dan Negara-Negara Gulf Cooperation Council (GCC). Adapun penentuan sampelnya menggunakan teknik Purposive Sampling, yaitu teknik penentuan sampel dengan pertimbangan tertentu. Adapun ketentuan yang digunakan yaitu :

a. Bank umum syariah yang terdapat di negara Indonesia, Malaysia dan Negara-negara Teluk Arab (Gulf Cooperation Council (GCC)).

b. Bank syariah tersebut menerbitkan laporan keuangan tahunan pada periode 2008-2015 secara konsisten dan telah dipublikasikan. c. Bank syariah tersebut memiliki data yang dibutuhkan terkait pengukuran variabel-variabel yang digunakan untuk penelitian selama periode 2008-2015.

Berdasarkan ketentuan di atas, diperoleh 16 (enam belas) bank umum syariah.

\section{Definisi Operasional Variabel Risiko Pembiayaan (RP) \\ Risiko Pembiayaan} digunakan untuk mengukur tingkat permasalahan Performing pembiayaan yang dihadapi oleh bank syariah. RP dapat diukur dengan rasio Non Financing (NPF).

Rasio NPF dapat dirumuskan sebagai berikut (Mawardi, 2005) :

$\begin{array}{cc}\text { Non } & \begin{array}{c}\text { Total Pembiayaan } \\ \text { Permasalah }\end{array} \\ \text { Financing }= & \text { Total Pembiayaan }\end{array}$

\section{Proporsi Pembiayaan Non Investasi (PPNI)}

Pembiayaan Non Investasi (PPNI) bank syariah mengacu pada pembiayaan dengan tingkat tetap (sisi piutang). Produk Pembiayaan Non Investasi diantaranya seperti Murabahah, Salam, Istishna de dan Ijarah. PPNI diukur dengan rasio Loan Asset to Total Asset (LATA) (Farook dkk., 2009).

$$
\text { LATA }=\frac{\text { Loan Asset }}{\text { Total Asset }} \times 100 \%
$$

\section{Profit Distribution Management (PDM)}

Berdasarkan hasil penelitian Farooq dkk (2009) ukuran yang paling efektif untuk menghitung Profit Distribution Management (PDM).yaitu dengan menggunakan asset spread. Asset Spread dapat 


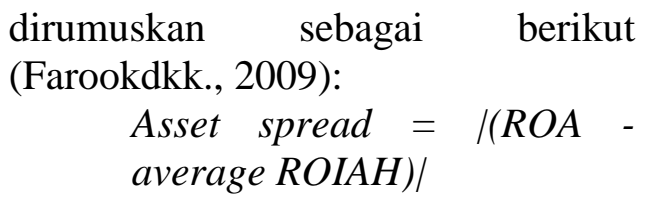

\section{Analisis Data}

Tahap-tahap dalam menganalisis data adalah melakukan uji statistik deskriptif, uji asumsi klasik dan uji hipotesis dengan analisis regresi berganda. Uji asumsi klasik yang dilakukan yaitu uji normalitas, uji autokorelasi, uji heteroskedastisitas dan uji multikolinieritas.

Penelitian ini menggunakan analisis statistik regresi berganda bertujuan untuk mengukur pengaruh risiko pembiayaan dan proporsi pembiayaan non investasi terhadap Profit Distribution Management (PDM) dengan menggunakan program aplikasi SPSS IBM 21. Persamaan Regresi dengan data panel adalah sebagai berikut :

$$
\mathrm{Y}=\mathrm{a}+\mathrm{b}_{1} \mathrm{X}_{1}+\mathrm{b}_{2} \mathrm{X}_{2}
$$

Keterangan :

$\begin{array}{lll}\mathrm{Y} & : \text { Profit Distribution } \\ & \text { Management (PDM) } \\ \mathrm{a} & : \text { Konstanta } & \\ \mathrm{b} 1, \mathrm{~b} 2 \mathrm{:} & \text { Koefisien variabel } \\ & \text { independent } \\ \mathrm{X}_{1} \quad: \text { Risiko pembiayaan } \\ \mathrm{X}_{2} \quad \text { : Proporsi pembiayaan non } \\ & \text { investasi }\end{array}$

Kemudian mengukur koefisien determinasi $\left(\mathrm{R}^{2}\right)$ untuk mengukur seberapa jauh kemampuan model dalam menerangkan variabel dependen. Terakhir, melakukan uji hipotesis dengan menentukan hipotesis statistik, menentukan $\mathrm{t}$ dan $\mathrm{F}$ hitung, menentukan $\mathrm{t}$ dan $\mathrm{F}$ tabel dan menentukan kriteria pengujian hipotesis.

\section{HASIL PENELITIAN DAN PEMBAHASAN}

NPF rata-rata tertinggi yaitu $4,07 \%$ yang terdapat pada bank syariah di Indonesia. Sedangkan NPF rata-rata terendah terdapat pada bank syariah di Kuwait. Rasio NPF tertinggi berasal dari Bank Muamalah Indonesia (Indonesia) yaitu sebesar $7,11 \%$. Adapun rasio NPF terendah Boubyan Bank (Kuwait) sebesar 0,01\%.

Rasio LATA rata-rata berada pada kisaran 45,42\% - 68,01\%. Rasio LATA tertinggi berada pada bank Al Rajhi Saudi Arabia (Saudi Arabia) yaitu sebesar 85,29\%. Sedangkan rasio LATA terendah berada pada Bank Muamalah Indonesia (Indonesia) 28,18\%.

$$
\text { Profit }
$$

Distribution

Management (PDM) dalam penelitian ini diukur dengan menggunakan asset spread. Nilai PDM tertinggi berasal dari Standard Chartered Saadiq Berhad (Malaysia). Nila PDM terendah berasal dari yaitu Al Rajhi Banking Malaysia
(Malaysia).

\section{Uji Asumsi Klasik}

Berdasarkan hasil pengujian (lihat lampiran) bahwa diketahui $p$ value sebesar 0,6549. Jika kita bandingkan dengan $\alpha=0,05$, maka nilai probabilitas jauh lebih besar. Sehingga $p$-value $>\alpha(0,05)$ yaitu $0,6549>0,05, \mathrm{H}_{0}$ diterima. Dengan demikian dapat disimpulkan bahwa dalam penelitian ini sebaran nilai residual berdistribusi normal.

Berdasarkan hasil pengujian (lihat lampiran) menunjukkan nilai Durbin-Watson sebesar 2,009487, maka nilai DW lebih besar dari batas atas 1,550 dan kurang dari 2,450 (4- 
1,550) sehingga dapat disimpulkan bahwa tidak terjadi autokorelasi.

Hasil uji heteroskidastisitas (lihat lampiran) menunjukkan bahwa nilai $p$-value obs ${ }_{\text {-squar }} 0,0796>\alpha$ $(0,05)$ maka H0 diterima, berarti tidak ada heterokedastisitas.

Berdasarkan hasil pengujian

(lihat lampiran) bahwa nilai koefisien korelasi antar variabel independen berada di bawah 0.80 atau koefisien korelasi antar variabel independen $<0.80$, dengan demikian data dalam penelitian ini tidak terjadi multikolinieritas.

\section{Analisis Regresi Linier Berganda}

Berdasarkan hasil pengolahan data menggunakan program SPSS, dihasilkan persamaan regresi linier berganda sebagai berikut :

$$
\begin{aligned}
\mathrm{PDM}= & 1,357+0,261 \mathrm{RP}+0,066 \\
\text { PPNI } &
\end{aligned}
$$

Berdasarakan model regresi di atas dapat dijelaskan bahwa :

1. Konstanta sebesar 1,357 mengartikan bahwa jika variabel risiko pembiayaan dan proporsi pembiayaan non investasi bernilai 0 , maka nilai variabel Profit Distribution Management sebesar 1,357.

2. Koefisien regresi variabel risiko pembiayaan sebesar 0,261 mengartikan bahwa jika variabel risiko pembiayaan sebesar 1 , maka nilai variabel Profit Distribution Management akan mengalami kenaikan sebesar 0,261 .

3. Koefisien regresi variabel proporsi pembiayaan non investasi sebesar 0,066 mengartikan bahwa jika variabel resiko pembiayaan sebesar 1 , maka nilai variabel Profit
Distribution Management akan mengalami kenaikan sebesar 0,066 .

\section{Koefisien Determinasi}

Berdasarkan hasil pengujian (lihat lampiran) diketahui bahwa nilai $\mathrm{R}^{2}$ (adjusted $\mathrm{R}$ Square) adalah 0.063 . Nilai ini berarti bahwa sebesar 6,3\% perubahan variabel Profit Distribution Managemenet dapat dijelaskan oleh variabel risiko pembiayaan dan proporsi pembiayaan non investasi sedangkan 93,7\% dijelaskan oleh variabel lain diluar model.

\section{Pengujian Hipotesis}

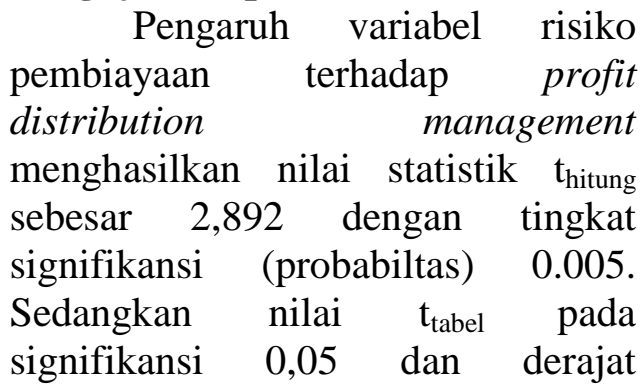
kebebasan $\mathrm{df}=\mathrm{n}-\mathrm{k}$ atau $128-6=122$ diperoleh nilai sebesar 1,282/ -1,282 dan tingkat signifikansi menunjukkan $0.005<0,05$. Dengan demikian, hipotesis ketiga yang diajukan dalam penelitian ini yang berbunyi risiko pembiayaan berpengaruh positif signifikan terhadap profit distribution management dapat diterima.

Pengaruh variabel proporsi pembiayaan non investasi terhadap profit distribution management menghasilkan nilai statistik $t_{\text {hitung }}$ sebesar 0,733 dengan tingkat signifikansi (probabiltas) 0,465. Sedangkan nilai $t_{\text {tabel }}$ pada signifikansi 0,05 dan derajat kebebasan $\mathrm{df}=\mathrm{n}-\mathrm{k}$ atau $128-6=122$ diperoleh nilai sebesar 1,282/ -1,282 dan tingkat signifikansi 
menunjukkan 0,465 > 0,05. Dengan demikian, hipotesis kedua yang diajukan dalam penelitian ini yang berbunyi proporsi pembiayaan non investasi berpengaruh positif signifikan terhadap profit distribution management tidak dapat diterima atau hipotesis ditolak.

Pengaruh variabel risiko pembiayaan dan proporsi pembiayaan non investasi secara simultan terhadap profit distribution management menghasilkan nilai statistik $F_{\text {hitung }}$ sebesar 4,185 dengan tingkat signifikansi (probabiltas) 0.005. Sedangkan nilai $F_{\text {tabel }}$ pada signifikansi 0,05 dan derajat kebebasan $\mathrm{df}=\mathrm{n}-\mathrm{k}$ atau $128-6=122$ diperoleh nilai sebesar 3,07 dan tingkat signifikansi menunjukkan $0,017<0,05$. Dengan demikian, hipotesis ketiga yang diajukan dalam penelitian ini yang berbunyi risiko pembiayaan dan proporsi pembiayaan non investasi secara simultan berpengaruh positif signifikan terhadap profit distribution management dapat diterima.

\section{Pembahasan}

\section{a. Pengaruh Risiko Pembiayaan terhadap Profit Distribution Management}

$$
\text { Apabila risiko }
$$

pembiayaan yang diukur dengan rasio NPF semakin tinggi, maka bagi hasil semakin kecil. Bila dikaitkan dengan teori stakeholder, maka bank syariah akan menaikan tingkat PDM yang mengacu pada suku bunga untuk memuaskan/mengelola deposannya. Hal ini karena dana yang tersalurkan sudah mengandung risiko yang tinggi sehingga akan menyebabkan bagi hasil menjadi rendah. Oleh karena itu bertambahnya tingkat PDM dikarenakan tingkat penditribusian bagi hasil yang diperoleh deposan sudah rendah akibat tingginya NPF dan untuk menghindari risiko displacement fund, yaitu kemungkinan deposan akan memindahkan dananya dari bank syariah ke bank konvensional.

b. Pengaruh Proporsi Pembiayaan Non Investasi terhadap Profit Distribution Management

Hasil penelitian ini tidak sejalan dengan hasil penelitian yang diperoleh pada penelitian terdahulu, karena besar atau kecilnya proporsi pembiayaan non investasi tidak akan mempengaruhi profit distribution management. Situasi tersebut terjadi karena biaya non investasi merupakan dana tetap yang harus selalu dikeluarkan walaupun kondisi kinerja bank syariah menurun. Keadaan tersebut mengakibatkan stakeholders lebih suka mengamati variabel lain yang dianggap lebih mempengaruhi profit distribution management seperti posisi likuiditas, laba dan berbagai variabel lainnya.

c. Pengaruh Resiko Pembiayaan dan Proporsi Pembiayaan Non Investasi terhadap Profit Distribution Management

Tidak selamanya kenaikan jumlah dana yang disalurkan (pembiayaan) akan 
menaikan pula tingkat bagi hasil, sebab setiap pembiayaan akan mengandung risikonya. Dimana akan ada kemungkinan pembiayaan tersebut tidak dapat tertagih sepenuhnya. Sehingga semakin baik kualitas pembiayaan yang disalurkan bank, semakin kecil tingkat risikonya yang dalam hal ini diukur dengan NPF. Oleh karena itu, bank harus memperhatikan tingkat NPF. NPF merupakan rasio untuk mengukur kemampuan bank dalam menjaga risiko kegagalan pengembalian pembiayaan oleh debitur. Sedangkan kenaikan atau penurunan pembiayaan non investasi tidak berpengaruh terhadap PDM bisa terjadi karena tidak kenaikan pembiayaan non investasi yang diberikan bank syariah dapat langsung mempengaruhi bagi hasil untuk pembiayaan investasi. Hal ini karena semakin tinggi pembiayaan non investasi menimbulkan resiko pembiayaan yang semakin tinggi pula.

\section{KESIMPULAN DAN SARAN \\ Kesimpulan}

1. Risiko Pembiayaan (RP) berpengaruh positif terhadap Profit Distribution Management (PDM)

2. Proporsi Pembiayaan Non Investasi (PPNI) tidak berpengaruh positif terhadap Profit Distribution Management (PDM)

3. Risiko Pembiayaan (RP) dan Proporsi Pembiayaan Non Investasi (PPNI) berpengaruh positif terhadap Profit
Distribution

Management (PDM)

\section{Saran}

1. Bank syariah harus mampu memperkecil risiko pembiayaan agar bank syariah tidak perlu meningkatkan Profit Distribution Management (PDM).

2. Bank syariah harus mampu meningkatkan proporsi pembiayaan non investasi untuk meningkatkan Profit Distribution Management (PDM).

3. Disarankan kepada peneliti lainnya untuk dapat menambahkan faktor-faktor lainnya, terutama faktor eksternal bank untuk dijadikan variabel independen. Dengan demikian penelitian sejenis dapat memberikan hasil yang lebih generalisasi.

\section{DAFTAR PUSTAKA}

Mangkuto, Imbang J. 2004. "Pengaruh Tingkat Suku Bunga Deposito Bank Konvensional dan Tingkat Pendapatan Deposito Mudharaba Terhadap Pertumbuhan Deposito di Bank Muamalat.Tesis PSKTTI UI.

Triyuwono, Iwan. 2003. "Sinergi Oposisi Biner: Formulasi Tujuan Dasar Laporan Keuangan Akuntansi Syaria'ah". IQTISAD Journal of Islamic Economics, Vol. 4, No. 1, h. 79-90. Diakses dari http://journal.uii.ac.id

Tamba, Erida Gabriella Handayani. 2011. "Pengaruh Struktur Kepemilikan Terhadap 
Pengungkapan Tanggung Jawab Sosial Perusahaan (Studi Empiris pada Perusahaan Manufacturing Secondary Sectors yang Listing di BEI tahun 2009)".

Chariri, A., and Ghozali, I..2007. Teori Akuntansi. Semarang: Badan Penerbit UNDIP.

Farook,S., M.K. Hassan, \& G. Clinch. 2011. "Profit distribution management by Islamic banks: An empirical investigation". The Quarterly Reviewof Economics and Finance, 52, 333-34.

Zaheer, S. 2013. Financial Intermediation and Monetary Transmission Through Conventional and Islamic Channels. Disertasi. University oh Amsterdam, Belanda. 


\section{LAMPIRAN}

\section{Gambar 1}

Uji Normalitas

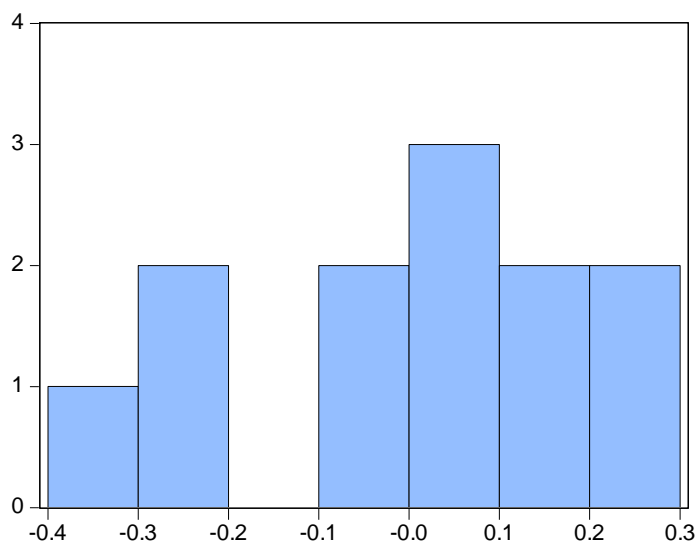

Series: Standardized Residuals

Sample 20082015

Observations 128

Mean $\quad-3.42 e-15$

Median $\quad 0.034704$

Maximum $\quad 0.271122$

Minimum $\quad-0.341718$

Std. Dev. $\quad 0.204186$

Skewness $\quad-0.340205$

$\begin{array}{ll}\text { Kurtosis } & 1.890810\end{array}$

Jarque-Bera $\quad 0.846630$

Probability $\quad 0.654872$

Tabel 1

Uji Autokorelasi

Effects Specification

\begin{tabular}{cccr}
\hline \hline \multicolumn{4}{c}{ Cross-section fixed (dummy variables) } \\
\hline \hline R-squared & 0.993248 & Mean dependent var & 3.666667 \\
Adjusted R-squared & 0.975241 & S.D. dependent var & 1.154701 \\
S.E. of regression & 0.181692 & Akaike info criterion & -0.459303 \\
Sum squared resid & 0.099036 & Schwarz criterion & -0.095623 \\
Log likelihood & 11.75582 & Hannan-Quinn criter. & -0.593950 \\
F-statistic & 55.16042 & Durbin-Watson stat & 2.009487 \\
Prob(F-statistic) & 0.003597 & & \\
\hline \hline
\end{tabular}

Tabel 2

Uji Heteroskedastisitas

\begin{tabular}{cccc}
\hline $\begin{array}{c}\text { Model } \\
\text { Persamaan }\end{array}$ & $\begin{array}{c}\text { Obs }{ }^{*} \text { R- } \\
\text { square }\end{array}$ & $\begin{array}{c}\text { Probabilitas } \\
(\text { chi-square })\end{array}$ & Kesimpulan \\
\hline I & 6.28291 & 0.0796 & Tidak ada heteroskedastisitas \\
\hline
\end{tabular}

Tabel 3

Uji Multikolonearitas

\begin{tabular}{|c|r|r|r|}
\hline & \multicolumn{1}{|c|}{ PDM } & \multicolumn{1}{|c|}{ RP } & \multicolumn{1}{c|}{ PPNI } \\
\hline PDM & 1 & 0.16668 & 0.017405 \\
\hline RP & 0.16668 & 1 & -0.27888 \\
\hline PPNI & 0.017405 & -0.27888 & 1 \\
\hline
\end{tabular}


Tabel 4

Uji t

Coefficients $^{a}$

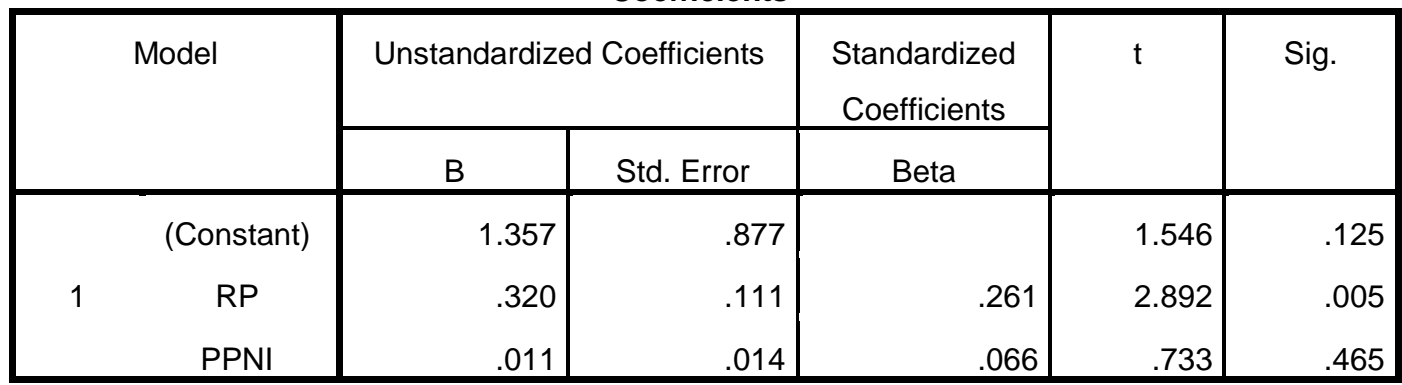

a. Dependent Variable: PDM

Tabel 5

Uji F

ANOVA $^{\mathrm{a}}$

\begin{tabular}{|c|c|c|c|c|c|c|}
\hline & Model & Sum of Squares & df & Mean Square & $\mathrm{F}$ & Sig. \\
\hline & Regression & 35.241 & 2 & 17.621 & 4.185 & $.017^{b}$ \\
\hline 1 & Residual & 526.304 & 125 & 4.210 & & \\
\hline & Total & 561.545 & 127 & & & \\
\hline
\end{tabular}

a. Dependent Variable: PDM

b. Predictors: (Constant), PPNI, RP

Tabel 6

Koefisien Determinasi

Model Summary

\begin{tabular}{|c|r|r|r|r|r|}
\hline Model & $\mathrm{R}$ & $\mathrm{R}$ Square & \multicolumn{1}{|c|}{$\begin{array}{c}\text { Adjusted R } \\
\text { Square }\end{array}$} & $\begin{array}{c}\text { Std. Error of the } \\
\text { Estimate }\end{array}$ & Durbin-Watson \\
\hline 1 & $.251^{\mathrm{a}}$ & .063 & .048 & 2.05193 & .783 \\
\hline
\end{tabular}

a. Predictors: (Constant), PPNI, RP

b. Dependent Variable: PDM 